\title{
Spanish Civil War in the construction of Neorealist Greek Cinema: an introductory study of Nikos Koundouros' To Potami
}

Sergio Villanueva Baselga, Universitat de Barcelona

\section{Abstract}

The film director Nikos Koundouros is one of the most important representatives of the Neorealist Greek Cinema that bloomed in Greece after the Civil War occurred in that country from 1946 to 1949 . This film movement was highly influenced by another war conflict that took place a decade before: the Spanish Civil War. This brief research will examine, through pictorial and semiotic analyses, the film To Potami/The River by Nikos Koundouros to elucidate whether this filmmaker was influenced by the Spanish conflict and how he translated it to his film. Therefore, this project will shed light to the study of the common historical grounds of Greece and Spain and, at the same time, to the emergent field of Southern Europe cultural studies.

Keywords: Spanish Civil War, Greek Neorealim, Film semiotics, Southen Europe Until three decades ago, the concept of 'Southern Europe' had no place in academic terminology. Nonetheless, with the advent of European integration ${ }_{2}$ many scholars began to notice that there existed striking similarities mainly between Portugal, Spain, Italy and Greece: economic backwardness, social divisions, political instability and similar patterns of behavior were but a few of the common factors that linked them together. The almost simultaneous collapse of the dictatorships in Portugal, Greece and Spain in the mid-1970s, the transition to democracy and the move towards the European Union confirmed the usefulness of this term as a coherent unit of analysis (Gunther et al, 1995). 
Far from current academic trends, which argue for the importance of national particularities and cultural exceptionalisms, new historians seek a deeper understanding of the analogies, common elements between histories of different countries, and the often unexpected connections that shed light on cross-national phenomena. This is the case of Greece and Spain, two countries that have had parallel histories, especially in the last century. Their respective Civil Wars - in Spain from 1936 to $1939_{2}$ and in Greece from 1946 to 1949 _ constitute some of the converging elements of their common histories. The effects of these conflicts on their respective national contexts are essential to understand most of their current problems and cultural spheres (Clogg 1992: Paredes Alonso_1998).

\section{Spanish and Greek Civil Wars in National Cinemas}

Both Civil Wars were underrepresented in their particular national cinemas until very recently, due to censorship and the imposition of the winners' versions over the collective memory. In Spain, films about the Civil War that were not supportive of the winners perspective were banned for forty years during the Francoist dictatorship. The same censorship took place in Greece, where Greek Civil War was not fictionalized until the end of the Coronels' regime, in 1974 (Karalis, 2012). It was only after this year and the restoration of democracy that the long-lasting post-Civil War era came to a close, at least on an institutional level, with the decriminalization of communism and the rehabilitation of the exiled and imprisoned left-wingers. Thus, it has often been argued that pre-dictatorship Greek cinema suffered from strong historical amnesia since, as it has been most commonly accepted, the actual national history, both recent and distant, was of little concern, while the traumatic experience of the Civil War and its painful consequences were completely absent (Vamvakidou 2013; Korneis 2014). 
The presence of Civil Wars in both Spanish and Greek national cinemas has been widely studied (Fernández Cuenca 1976; Heredero 1993; Andritsos 2005; Flitouris 2008). Meanwhile, cross-reflections of these conflicts in reciprocal national cinemas have not been analyzed yet. As shown by Rodríguez Milán (2007), Greek interest in the Spanish Civil War has been higher than the Spanish equivalent for the Greek conflict. In this line, Fillipis (2008) carried out a revision of the influence that Spanish Civil War had on Greek literature and showed that, for instance, the publication in 1944 of The ball of the Reaper by Teo Papamanolis,

Con formato: Fuente: Cursiva Greek correspondent reporter in Spain during the Civil War, had a great impact in the Hellenic country that even influenced government decisions. In relation to film, Chalkou (2008) points out that film festivals devoted to national cinemas took place sporadically in the 1950s, including the Festival of Spanish Cinema in Athens, and the Thessaloniki Film Festival in 1951 (Chalkou, 2008: 70). Therefore, one can inductively think that there exist more references to the Spanish Civil War in Greek Cinema than on the contrary.

Greek presence in fictions about Spanish Civil War goes back to 1943, when Katina Paxinou made her film debut ${ }_{2}$ not in a Greek production, but in a foreign one: For Whom the Bell Tolls, directed by Sam Wood, was a Paramount film based on Hemingway's novel of the Spanish Civil War. Paxinou won an Oscar for her supporting role in her portrayal of Pilar (Tzavalas 2012: 57), before taking part, in 1945, in the film Confidential Agent, an adaptation of Graham Greene's story set in the Spanish Civil War (Tzavalas 2012: 59).

In post-war Greece, the limited treatment of historical themes and their depiction from the nationalistic perspective are generally attributed to the poor financial and technical capabilities of the Greek industry. In turn, this fact 
prevented historical reconstructions, enforcing the official ideology through strict censorship, the producers' reluctance to risk being banned (with the subsequent commercial failure), and the difficulty of dealing with a subject that was so divisive and controversial. Nonetheless, some Greek directors - most of whom were part of the blooming of Neorealism - broke the silence in the 1950s. Roviros Manthoulis' film Psila ta Heria Hitler / Hands Up Hitler (1962), and Nikos Koundouros' outputs Oi Paranomoi/The Outlaws (1958) and To Potami/The River (1960), were some of the most important representatives of Greek Neorealism who dared speak about the recent history of Greece and managed to elude censorship (Kolovos 2002: $162)$.

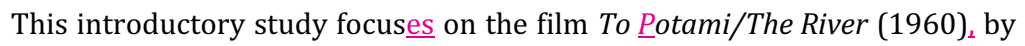
Nikos Koundouros $s_{L}$ and sheds light, through a pictorial and semiotic analysis, on how the Spanish Civil War had an impact_on Greek Neorealism. The article examines the ways in which To Potami combines stories of soldiers and guerrillas with aspects of Southern Europe history, expanding subjectivities beyond the national borders. Methodologically, this study is based on the recently established paradigm that cinema and popular culture can inform a historical project. From this perspective, cinema is not only an industry that includes companies, producers, directors and actors but a social institution that evolves alongside the society in which it is produced and viewed (Hadjikyriacou 2013: 1-2).

\section{To Potami/The River by Nikos Koundouros}

To Potami/The River, a film produced in 1959, was an adaptation of the homonymous short story written by Antonis Samarakis and other short stories by Iakovos Kambanellis, Notis Peryialis and Nikos Koundouros (Kalogeras 2011: 92; see Figure 1). Having edited two versions of the film, there was a prolonged 
disagreement between the director of the film, Nikos Koundouros, and the producers as to which of the two versions should be released. It was finally released in 1960, when it also entered into the Greek Film Festival at Thessaloniki.

Eliminado: was

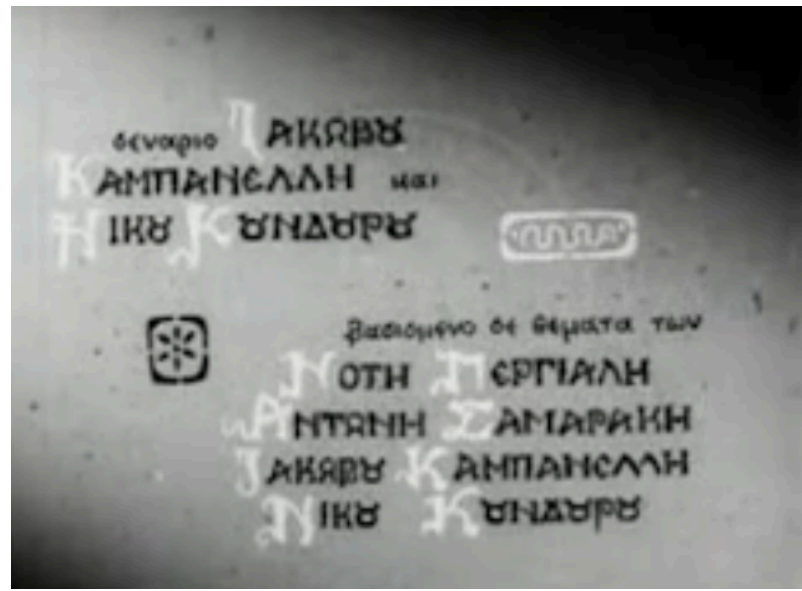

Figure 1. Caption of the starting credits of To Potami/The River, indicating the writers' names (Notis Peryialis, Antonis Samarakis, Iakovos Kambanellis and Nikos Koundouros]

To Potami/The River (1960) tells four different stories, all connected by the banks of a river, in which three bandits, a soldier, the daughter of a serviceman and a couple in love find themselves escaping from their own conflicts. The unifying subject is, in fact, the escape from the boggy shores of that river. Nikos Koundouros in his usual attempt to create something novel and original, $\underline{\text { strove for }}$ a product that was logical and artistic "making overt references to pictures of the Spanish Civil War" (Karalis 2012: 78). To Potami/The River does not explicitly depict the Greek Civil War or any other conflict, but uses a narrative that is closely related to warlike fictions and symbolisms commonly associated with military subjectivity. The film, moreover, opens with a tracking lateral shot that moves from a cross that is pinned into the soil to an almost dry river in a deserted 
landscape, that resembles both the Thessaly plain and the Castilian meseta. These two symbols re-appear in the interlinked histories presented in the film, building the foundations of the internal and external conflicts of the main protagonists.

The cross and the river can be understood as the main symbols in the narrative construction of the war intertwining its poetic logic with key elements of both the Spanish and the Greek Civil Wars. The cross, on the one hand, directs the action of the three bandits ${ }_{2}$ who are torn between military action and religiosity. The story of the three bandits is the one that speaks more openly about the incongruous attitudes that religious men and women had in both conflicts. The river, on the other hand, is the place where the three bandits hide not only from the soldiers but also from themselves. Meanwhile, the river saves the little girl from being trapped by the entourage of his father, the military man, and it also kills the soldier who, driven by his curiosity and disobeying his officer's orders, decides to swim in it before being discovered by the enemy. The river is understood, thus, as a representation of trenches, boundaries and artificial borders built by and against civilians in civil wars.

The stifling and drowning presence of the river - which was, by the way, also present in Oi Paranomi/The Outlaws (1958)_ provides the nexus that connects Nikos Koundouros' masterpieces with the Spanish Civil War. It should be recalled that none of the battles in the Greek Civil War took place by a river but in mountainous topographies, such as the battle of Grammos-Vitsi, which put an end to the Greek dispute. However, in the Spanish case, several rivers became the setting of key military operations and dramatic events such as the battles of Jarama and Ebro, which had a significant international impact on left-wingers across Europe. The compositions created by Koundouros in To Potami/The River 
resemble the photographs taken by Robert Capa during those battles, perhaps suggesting that this director had already seen these images (see Figure 2). Besides, the original short story by Antonis Samarakis the film adapted was published in 1954 under the anthology Zitite Elpis/In search of hope which reflected the depressing mood of the human being after the Spanish Civil War and_World War $\underline{\text { II }}$.

A
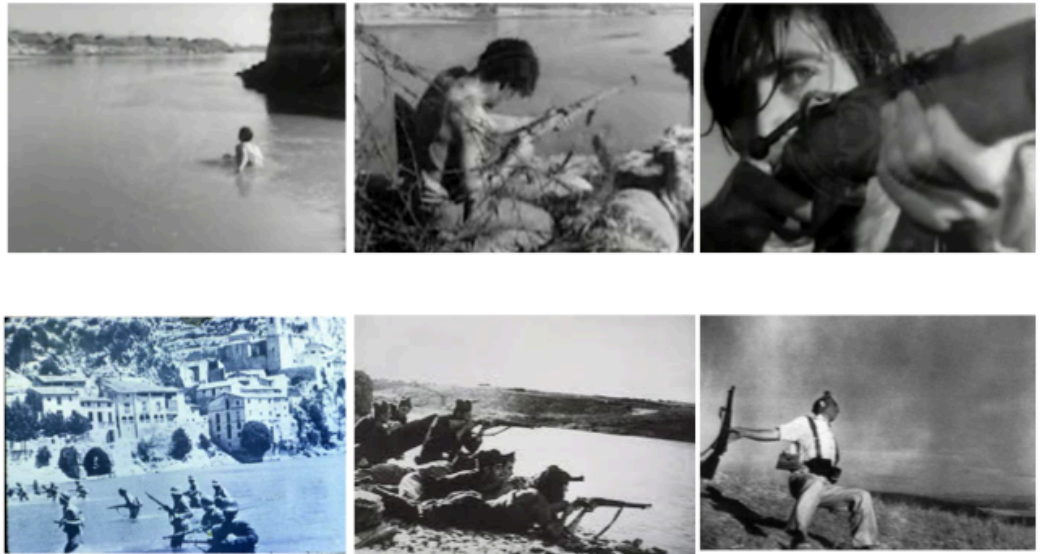

Figure 2. Al Captions of the film_To Potami/The River, in which the river has a significant symbolism. B) Photographs taken by Robert Capa of the Battle of Ebro during the Spanish Civil War.

Finally, another aspect that points towards the impact that the photographs of the Spanish Civil War had on Koundouros' film is the character of the small child. Dressed with a loose coat and shepherding a herd of bulls, this child $\underline{\text { represents the overwhelming responsibility of the Spanish Second Republic, which }}$ has the duty to conduct the flock and protect a weak Spanish democracy (see Figure 3). 


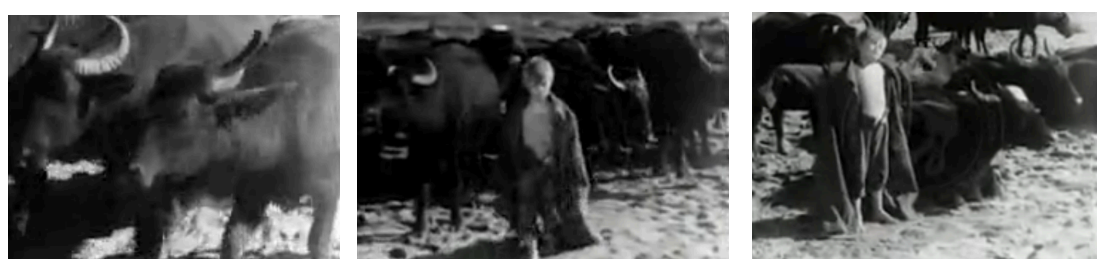

Figure 3. The child and the herd of bulls as a symbol of the overwhelming responsibility of the Spanish Second Republic.

\section{Discussion and Conclusions}

This article has succinctly outlined the influence that narratives and photographs of the Spanish Civil War had on the film To Potami/The River by Nikos Koundouros. The director may have discovered these materials in the exhibition held in the 1951 edition of the Thessaloniki Film Festival ${ }_{2}$ and in the different publications about the war that were produced in the 1950s. This influence is also present in the film The Outlaws/Oi Paranomoi (Karalis 2012: 78), making it necessary to extrapolate the analysis performed in this brief study to this film.

This study follows many other recent Lacanian perspectives on Greek cinema such as Kosma's (2012) psychoanalytic reading of Ta Kitrina Gantia/Yellow Gloves, a popular film of the 1960s. Kosma's reading of the narrative reveals not only how popular cinema functions as a space for the negotiation of gendered identities, but also how it reproduces the cultural anxieties of a society in transition. From the same perspective ${ }_{2}$ Achilleas Hadjikyriacou examines the film Stella by Cacoyanis, which represents the transformation of patriarchy in 1950s Greece. Hadjikyriacou argues that the masculinities in crisis presented in the film are not challenged by an imported modernity in Greece.

Civil Wars have also been analysed following a poststructuralist approach (Vamvikidou 2013; Kornetis 2014). Kornetis, for instance, has performed a post- 
structuralist analysis of the Greek Civil War in the films Psyhi Vathia/ A soul so Deep (2009), by Pantelis Voulgaris, and Demeni Kokkini Klosti/Tied Red Thread Kostas Charalmbous. $\underline{\text { Kornetis }}$ argued that these two films symbolize the transition from a cinema of reconciliation ${ }_{\nu}$ that was promoted around $2008_{2}$ to $\underline{\text { a }}$ cinema of vengeance and ultra-violence $\_$that became inextricably linked to the general political reconfiguration of the country since the civil unrest of 2008 and the onset of the economic crisis.

Nuria Triana-Toribio argue $\underline{\underline{s},}$ in relation to Francoist Spanish National Cinema, that

in Freud's model of the unconscious, desires and drives which are incompatible with the dominant psychical system are pushed out of sight, censored by consciousness; however, these desires can never be fully eliminated, and return, after undergoing condensation or displacement, in distorted or unrecognizable forms (Triana-Toribio 2003:_97).

Therefore, according to this view, political issues and themes that were excluded from Greek cinema due to censorship rules eventually became present again. This analysis has shown some of the ways in which the Spanish Civil War was present in the impulse to break the norm established by the post-civil war regime in Greece $_{\iota}$ through the construction of warlike narratives in Nikos Koundouros' Neorealist cinema.

\section{Aknowledgements}

This brief study would have been impossible without the enthusiastic help of Teresa Magadan and Kleri Skandami from the Modern Greek Department at Barcelona-Drassanes Escola Oficial d'Idiomes and the support of School of Modern Greek Language of the Aristotle University of Thessaloniki. I would also like to 
thank Lydia Sánchez Gómez from Universitat de Barcelona for her reviews of the text and for encouraging me to perform this research.

\section{References}

Andritsos, Giorgios (2005) I Katochi Kai I Antistasi ston Elliniko Kinimatografo/Occupation and Resistance in Greek Cinema. Athens: Aigiokeros

Chalkou, Maria (2008) Towards the creation of 'quality' Greek national cinema in the 1960s. PhD thesis at University of Glasgow

Clogg, Richard (1992) A concise history of Greece. Cambridge: Cambridge University Press

Fernández Cuenca, Carlos (1976) La Guerra de España y el cine. Madrid: Filmoteca Nacional de España

Filippís, Dimitris (2008) Historia y Literatura: La Guerra Civil Española en Grecia. Madrid: del Orto

Flitouris, Lampros (2008) O emfylios sto seliloid: mnimes nikiton kai ittimenon ston elliniko kinimatografo/Civil war on celluloid: memories of victors and defeated in Greek cinema in Van Boeschoten Riki et al (eds), Mnimes kai Lithi tou Ellinikou Emfyliou/Memories and Oblivion of the Greek Civil War, Thessaloniki: Epikentro: 387-404.

Gunther, Richard, Diamandouros, Nikiforos, Puhle, Hans-Jürgen (1995) The politics of Democratic Consolidation: Southern Europe in a Comparative Perspective. Baltimore and London: The John Hopkins University Press.

Hadjikyriacou, Achileas (2012) Cacoyannis' Stella: Representation and Reception of a Patriarchal Anomaly. In: Papadimitriou, Lydia \& Tzioumakis, Yannis (eds) Greek cinema: Texts, Histories, Identities. Bristol: Intellect. 
- (2013) Masculinity and Gender in Greek Cinema: 1949-1967. New York \& London: Bloomsbury Publishing.

Heredero, Carlos F. (1993) Las huellas del tiempo. Cine español 1951-1961. Madrid: Ediciones Documentos Filmoteca.

Kalogeras, Yiorgos (2011) Retrieval and Invention: The Adaptation of Texts and the Narrativization of Photographs in Films on Immigration. Journal of Modern Greek Studies. 29(2): 153-170

Kalyvas, Stathis (2008) How not to Compare Civil Wars: Greece and Spain, in Martin Baumeister, Martin \& Schüler-Springorum, Stefanie (eds.), "If you tolerate this..." The Spanish Civil War in the Age of Total War. Munich: Campus Verlag Gmbh

Karalis, Vrasidias (2012) History of Greek Cinema. London: Bloomsbury academic Kolovos, Nikos (2002) Neos Ellinikos Kinimatografos in Neoelliniko Theatro

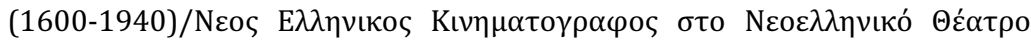
(1600-1940). Kinimatografos, O Ellinikos Kinimatografos, 2

Kornetis, Kostis (2014) From reconciliation to vengeance: the Greek Civil War on Screen in Pantelis Voulgaris's A soul so deep and Kostas Charalmbous's Tied Red Thread. FILMICOM: Journal of Greek Film Studies. 2

Kosma, Yvonne (2012) Gloves and Moustaches: Masculinity and Gender Relations in the Film Ta Kitrina Gantia/Yellow Gloves. In: Papadimitriou, L \& Tzioumakis, Y (eds) Greek cinema: Texts, Histories, Identities. Bristol: Intellect.

Koundouros, Nikos (1960) To potami. Athens: Finos Productions

Paredes Alonso, Francisco Javier (1998) Historia contemporánea de España/Spanish Contemporary History. Madrid: Ariel. 
Rodríguez Milán, Roberto (2007) Confrontaciones civiles en la Europa Mediterránea: Materiales para el estudio de la guerra civil griega. Hispania nova. Revista de Historia Contemporánea, 7.

Triana-Toribo, Nuria (2003) Spanish National Cinema. London: Routledge

Tzavalas, Trifon (2012) Greek Cinema - 100 Years of Film History 1900 - 2000. Los Angeles: Hellenic University Club of Southern California

Vamvakidou, Ifigenia (2013) Greek civil war and representations of power in Greek cinema (1948-2010). Journal of Critical Studies in Business \& Society, 4(1): 88-107 